\title{
Genetic relatedness and virulence factors of bovine Staphylococcus aureus isolated from teat skin and milk
}

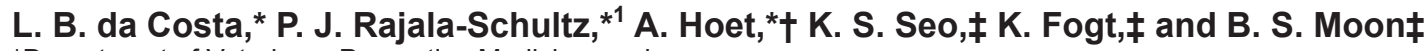 \\ *Department of Veterinary Preventive Medicine, and \\ †Division of Epidemiology, The Ohio State University, Columbus 43210 \\ ‡Department of Basic Sciences, Mississippi State University, Mississippi State 39762
}

\section{ABSTRACT}

The objective of this study was to assess the role of teat skin colonization in Staphylococcus aureus intramammary infections (IMI) by evaluating genetic relatedness of Staph. aureus isolates from milk and teat skin of dairy cows using pulsed-field gel electrophoresis and characterizing the isolates based on the carriage of virulence genes. Cows in 4 known Staph. aureus-positive herds were sampled and Staph. aureus was detected in 43 quarters of 20 cows, with 10 quarters positive in both milk and skin (20 isolates), 18 positive only in milk, and 15 only on teat skin. Quarters with teat skin colonized with Staph. aureus were 4.5 times more likely to be diagnosed with Staph. aureus IMI than quarters not colonized on teat skin. Three main clusters were identified by pulsed-field gel electrophoresis using a cutoff of $80 \%$ similarity. All 3 clusters included both milk and skin isolates. The majority of isolates $(72 \%)$ belonged to one predominant cluster (B), with $60 \%$ of isolates in the cluster originating from milk and $40 \%$ from teat skin. Genotypic variability was observed within 10 pairs (formed by isolates originating from milk and teat skin of the same quarter), where isolates in 5 out of the 10 pairs belonged to the same cluster. Forty-two virulence factors were screened using PCR. Some virulence factors were carried more frequently by teat skin isolates than by milk isolates or isolates from quarters with high somatic cell counts. Isolates in the predominant cluster $\mathrm{B}$ carried virulence factors $\operatorname{clf} A$ and $c l f B$ significantly more often than isolates in the minor clusters, which may have assisted them in becoming predominant in the herds. The present findings suggest that teat skin colonization with Staph. aureus can be an important factor involved in Staph. aureus IMI.

Key words: Staphylococcus aureus, milk and teat skin, pulsed-field gel electrophoresis, virulence factor

\footnotetext{
Received January 21, 2014.

Accepted July 21, 2014.

${ }^{1}$ Corresponding author: rajala-schultz.1@osu.edu
}

\section{INTRODUCTION}

Staphylococcus aureus is a major pathogen that can cause a wide variety of diseases in humans and animals. In cattle, Staph. aureus is often associated with IMI and is considered a contagious pathogen that is mostly transmitted from cow to cow during the milking process. Staphylococcus aureus usually causes subclinical infections with negative effects on milk quality and production, which also increases the risk of culling as well as labor, treatment, and replacement costs. A solid understanding of the epidemiology of Staph. aureus infections (e.g., sources and transmission of the organism) is crucial for an effective control program.

Results from the published literature regarding the role of teat skin as a source of Staph. aureus IMI are conflicting, and involvement of teat skin in Staph. aureus epidemiology is not fully understood (Zadoks et al., 2002; Haveri et al., 2008; Capurro et al., 2010). The use of molecular techniques, such as pulsed-field gel electrophoresis (PFGE; Haveri et al., 2007), binary typing (Zadoks et al., 2000), and multilocus sequence typing (MLST; Enright et al., 2000), has brought new insight but also more questions regarding this issue. Zadoks et al. (2002) concluded that most Staph. aureus mastitis cases are caused by strains highly adapted to the mammary gland and different from skin isolates. However, another study suggested that most Staph. aureus isolates from teat skin and teat canal were genetically indistinguishable from those isolated from infected mammary glands (Haveri et al., 2008). It has also been reported that isolates from extramammary sites (such as vagina, muzzles or nares, and hock skin) were indistinguishable from isolates found in milk (Capurro et al., 2010; Mørk et al., 2012). It remains unclear whether isolates originating from different sources belong to the same strain and trigger similar inflammatory response in the mammary gland and if they carry same virulence factors that contribute to the severity of IMI.

A limited number of Staph. aureus strains are typically detected within a herd with one predominant strain causing the majority of IMI (Joo et al., 2001; 
Table 1. Characteristics of the study herds (herd size and prevalence of bovine Staphylococcus aureus based on earlier sampling), number of cows and quarters sampled, and number of cows from which isolates originated, number of positive milk and teat skin samples, and average SCC value $\left(\times 10^{3}\right.$ cells $\left./ \mathrm{mL}\right)$ in quarters infected with Staph. aureus in the study herds

\begin{tabular}{|c|c|c|c|c|c|c|c|}
\hline \multirow{2}{*}{$\begin{array}{l}\text { Herd } \\
\text { ID }\end{array}$} & \multirow{2}{*}{$\begin{array}{l}\text { Herd } \\
\text { size }^{1}\end{array}$} & \multirow{2}{*}{$\begin{array}{c}\text { Herd } \\
\text { prevalence }(\%)\end{array}$} & \multirow{2}{*}{$\begin{array}{c}\text { No. of } \\
\text { cows/quarters } \\
\text { sampled }\end{array}$} & \multirow{2}{*}{$\begin{array}{c}\text { Source } \\
\text { cows (no.) }\end{array}$} & \multicolumn{3}{|c|}{ Positive samples } \\
\hline & & & & & Milk & Teat skin & $\mathrm{SCC}$ \\
\hline 1 & 140 & 15 & $15 / 60$ & 8 & 5 & 15 & 601 \\
\hline 2 & 201 & 8 & $15 / 60$ & 4 & 11 & 6 & 3,714 \\
\hline 3 & 97 & 7 & $12 / 48$ & 4 & 5 & 2 & 7,410 \\
\hline 4 & 128 & 6 & $15 / 60$ & 4 & 7 & 2 & 4,183 \\
\hline
\end{tabular}

${ }^{1}$ Includes both lactating and dry cows.

Tenhagen et al., 2007; Haveri et al., 2008). It has been suggested that low prevalence strains act similarly to environmental pathogens and could simply be colonizers of the skin and contaminants in the milk, and thus no or only a mild response would be detected in the mammary gland (Sommerhäuser et al., 2003; Fournier et al., 2008). It could be assumed that the predominant strains possess certain characteristics that have allowed them to become prevalent in a herd and to cause IMI. The capability of Staph. aureus to cause disease is related to several virulence factors that allow the organism to adhere to a surface, invade or avoid the immune system, and cause harmful effects to its host (Bien et al., 2011). Staphylococcus aureus is able to produce large array of toxins and other virulence factors that contribute to the manifestation and severity of staphylococcal infections and pathogenesis of mastitis (Sutra and Poutrel, 1994). There is a paucity of studies comparing carriage of virulence factors in bovine Staph. aureus isolates from different sources. The overall objective of the current study was to assess the association between teat skin colonization by Staph. aureus and Staph. aureus IMI by (1) evaluating genotypic relatedness of Staph. aureus isolates from milk and teat skin of dairy cows using PFGE, and (2) characterizing the isolates based on the carriage of virulence factors.

\section{MATERIALS AND METHODS}

\section{Selection of Herds}

Four Ohio dairy herds previously involved in other studies and known to have Staph. aureus IMI were included in the study. A whole-herd sampling, collecting composite milk samples from each lactating cow, had been conducted in these herds 2 to 6 mo before the cows were sampled for this study. Those milk culture results had revealed Staph. aureus IMI prevalence, on a cow level, of between 6 and $15 \%$ in these herds. Sample size calculation for the current study was based on an assumption that quarters colonized by Staph. aureus on teat skin would be 2 times more likely to have a Staph. aureus IMI than quarters not colonized (P. Rajala-Schultz, unpublished data). Based on this and on the results of the whole-herd sampling, 5 known Staph. aureus-positive cows, 5 cows with no previous Staph. aureus-positive cultures, and 5 cows with unknown status (not sampled in the herd testing) from each herd were randomly selected (www.random.org) to be enrolled in the study, except in herd 3, where 4, 4 , and 4 cows were sampled, respectively. In total, 57 cows in their first to third lactation were sampled and included in the study. Information about herd size and Staph. aureus herd prevalence is presented in Table 1. All herds practiced pre- and postmilking teat dipping, treated clinical mastitis cases with antibiotics, applied blanket dry-cow therapy, and had their milking equipment regularly serviced and properly maintained.

\section{Bacteriological Procedures and Identification of Staph. aureus}

Milk. In total, 228 quarter milk samples were aseptically collected immediately before routine milking following procedures described by the National Mastitis Council (Hogan et al., 1999). Milk samples and teat skin swabs from each quarter were collected using disposable latex gloves that were changed between each animal. Milk samples were transported in ice to the laboratory, and kept frozen for up to 1 wk until further processing. Milk samples were thawed at room temperature and $10 \mu \mathrm{L}$ of milk was plated on blood agar containing 5\% sheep blood (Remel Inc., Lenexa, KS) and on Staph. aureus selective BBL Chromagar plates (BD Diagnostic Systems, Sparks, MD). Plates were incubated at $37^{\circ} \mathrm{C}$ and checked for growth at 24 and 48 h. Staphylococcus aureus was phenotypically identified based on colony morphology (rose to mauve colonies on Chromagar plates) and hemolysis, Gram stain, positive catalase test, and positive tube coagulase rabbit plasma test, which was read at 4 and $24 \mathrm{~h}$. Colony counts on each plate were recorded and a sample with $\geq 1 \mathrm{cfu} / 10$ 
$\mu \mathrm{L}$ of milk was considered positive. From each positive sample, a representative single colony was subcultured on a blood agar plate and the 24-h growth was stored at $-80^{\circ} \mathrm{C}$ until further processing. The SCC in each quarter milk sample was determined in the local DHI laboratory using a set of fresh milk samples collected at the same time as the aseptic samples.

Teat Skin Swabs. A total of 228 teat skin swabs were collected from the same cows and quarters at the same milking as the milk samples but before teat preparation. If teats were visually soiled, dry paper towels were used to clean the teats before collecting the swab samples. To cover the entire surface of the teat barrel, a cotton swab soaked in tryptic soy broth (TSB; BD Diagnostic Systems) was rolled from the teat base over the teat end to the opposite teat base, followed by rotation of the swab in a manner that the whole teatbarrel surface would be covered with 10 such rotations. An individual swab was used for each teat, and gloves were changed between animals. After collection, swabs were immediately placed into sterile tubes filled with $5 \mathrm{~mL}$ of TSB and transported in ice to the laboratory for processing. In the laboratory, TSB tubes containing the sampled swabs were incubated at $37^{\circ} \mathrm{C}$ overnight, and $10 \mu \mathrm{L}$ of the solution was plated on Chromagar and blood agar plates containing $5 \%$ sheep blood. All plates were incubated at $37^{\circ} \mathrm{C}$ and checked for growth at 24 and $48 \mathrm{~h}$; colonies were identified as Staph. aureus using the same criteria as for milk. From each positive sample, a single representative colony was subcultured on a blood agar plate and the 24 -h growth was stored at $-80^{\circ} \mathrm{C}$ until further processing. For the purpose of the study, an isolate was defined as "a pure culture of bacteria obtained by subculture of a single colony from a primary isolation plate, presumed to be derived from a single organism, for which no information is available aside from its genus and species" (Tenover et al., 1995).

$\boldsymbol{P F G E}$. One milk and skin isolate from each positive quarter was selected for PFGE analysis. The procedure was performed according to a Canadian standardized PFGE method for Staph. aureus subtyping as previously described (Mulvey et al., 2001). Briefly, PFGE assays were performed on overnight bacterial cultures. Concentrations of bacterial cell suspensions were adjusted by diluting with sterile cell suspension buffer (10 $\mathrm{m} M$ Tris-HCl, $20 \mathrm{~m} M \mathrm{NaCl}$, and $50 \mathrm{~m} M$ Tris EDTA) to an optical density of 1.35 by spectrophotometer using a wavelength of $610 \mathrm{~nm}$. Lysostaphin $(2 \mu \mathrm{L}$ of 1 $\mathrm{mg} / \mathrm{mL}$ ) was added to $150 \mu \mathrm{L}$ of each bacterial cell suspension and gently mixed; then, $150 \mu \mathrm{L}$ of $2 \%$ lowmelting-point agarose was added and gently mixed by pipetting. Approximately $100 \mu \mathrm{L}$ was dispensed into molds to form agarose plugs. Agarose plugs with embedded bacterial cells were then lysed using lysis buffer
$(500 \mu \mathrm{L}, 10 \mathrm{~m} M$ Tris-HCl, $50 \mathrm{~m} M \mathrm{NaCl}, 50 \mathrm{~m} M$ EDTA, $0.2 \%$ deoxycholate, and $0.5 \% \mathrm{~N}$-lauryl sarcosine) and proteinase $\mathrm{K}(20 \mathrm{mg} / \mathrm{mL})$ in buffer $(250 \mathrm{mM}$ EDTA and $1 \% N$-lauryl sarcosine) and washed vigorously using wash buffer $(1.4 \mathrm{~mL}, 10 \mathrm{~m} M$ Tris- $\mathrm{HCl}$ and $0.1 \mathrm{mM}$ EDTA) at least 3 times on a shaker at $37^{\circ} \mathrm{C}$. Restriction enzyme buffer (REB) for SmaI (New England Biolab, Ipswich, MA) was diluted to $1 \times$, added to the tube containing one-fourth of a plugm and incubated at $25^{\circ} \mathrm{C}$ for $10 \mathrm{~min}$. The REB was removed from the tube without damaging the plug slice and $150 \mu \mathrm{L}$ of $1 \times \mathrm{REB}$ containing $25 \mathrm{U}$ of $S m a \mathrm{I}$ was added and incubated at $25^{\circ} \mathrm{C}$ for at least $2 \mathrm{~h}$. The digested plugs were embedded in a special agarose (Nusieve Agarose for PFGE, FMC BioProducts, Rockland, ME) and then separated using a CHEF-DRIII (Bio-Rad, Hercules, CA) apparatus under the following conditions: voltage $(6 \mathrm{~V} / \mathrm{cm})$, initial switch time of $5.3 \mathrm{~s}$, and final switch time of 34.9 s for 19 h. One plug of Salmonella serovar Braenderup H9812 was used as a standard reference.

\section{Virulence Factors in Milk and Teat Skin Isolates}

Forty-two virulence factors, including 14 cytotoxins (hla, hlb, hld, hlgA, hlgB, hlgC, lukA, lukB, lukD, lukE, lukM, lukF', lukF-pv, lukS-pv), 9 adhesion factors (chp, clf $A$, clfB, ear, ebh, emp, fnbA, fnbB, fbpA), and 19 enterotoxins (sea, seb, sec, sed, see, seg, seh, sei, sej, sek, sel, sem, sen, seo, sep, seq, ser, seu, and tsst-1) were screened for by using several multiplex PCR as described elsewhere (Jarraud et al., 2001; Tristan et al., 2003; Park et al., 2011), with minor modifications.

Briefly, multiplex PCR were performed with AmpliTaq Gold polymerase system (Applied Biosystems, Foster City, CA). Each reaction mixture $(50 \mu \mathrm{L})$ contained $5 \mu \mathrm{L}$ of $10 \times$ PCR reaction buffer, $200 \mu M$ deoxynucleoside triphosphates (Applied Biosystems), 3 $\mathrm{mM} \mathrm{MgCl} 2,200 \mathrm{n} M$ each primer, $2.0 \mathrm{U}$ of AmpliTaq Gold polymerase (Applied Biosystems), and $10 \mathrm{ng}$ of chromosomal DNA. The cycling conditions consisted of initial denaturation at $94^{\circ} \mathrm{C}$ for $10 \mathrm{~min}$, followed by 35 cycles of denaturation at $94^{\circ} \mathrm{C}$ for $30 \mathrm{~s}$, annealing at $58^{\circ} \mathrm{C}$ for $30 \mathrm{~s}$, and extension at $72^{\circ} \mathrm{C}$ for $30 \mathrm{~s}$, and ending with a final extension at $72^{\circ} \mathrm{C}$ for $10 \mathrm{~min}$. The PCR products were resolved by electrophoresis in $2.0 \%$ agarose gels with $0.5 \times$ Tris-acetate-EDTA buffer, stained with ethidium bromide, and visualized under UV light.

\section{Genotypic and Statistical Analysis}

The PFGE results for all isolates used in this study were analyzed with Bionumerics software (Applied Maths, Sint-Marten, Belgium). Cluster analysis was performed by the unweighted pair-group method with 
arithmetic averages (UPGMA) to generate a dendrogram. Banding patterns were compared by using Dice coefficient with a position tolerance of $2.0 \%$. A cut-off value of $80 \%$ was applied to interpretation of the banding patterns. Two or more isolates were considered to form a cluster if they had over $80 \%$ similarity; isolates were considered a pulsotype if they were $100 \%$ similar.

The strength of association between finding Staph. aureus on teat skin and Staph. aureus IMI in the same quarter was assessed by calculating relative risk and its $95 \%$ confidence interval. Association between the source (milk or teat skin) and carriage of different virulence factors was tested using chi-squared test of independence or Fisher's exact test, as appropriate. Similarly, proportions of isolates carrying virulence factors across different PFGE clusters and from Staph. aureus-infected quarters with high and low SCC (categorized into 2 groups, using a cut-off of 400,000 cells/ $\mathrm{mL}$ ) were compared using chi-squared test of independence or Fisher's exact test, as appropriate, using Stata 10.0 (StataCorp, College Station, TX). This relatively high cut-off of 400,000 cells/mL was used to classify the quarters as high and low based on somatic cells, because only 3 infected quarters had SCC $<400,000$ cells/mL. Somatic cell count was transformed to linear score (SCS) and the nonparametric Wilcoxon signed rank test was used to compare SCS in quarters that gave rise to isolates in different clusters.

\section{RESULTS}

\section{Prevalence of Staph. aureus in Milk and Teat Skin}

Staphylococcus aureus was detected in 28 (12\%) of the 228 milk samples collected and in 25 (11\%) of the 228 teat skin samples. Numbers of Staph. aureus-positive samples from milk and teat skin in the study herds, as well as basic information about the herds, are presented in Table 1. In total, Staph. aureus was detected in 20 cows and 43 quarters. Of these quarters, 10 (23\%) were positive both for milk and skin, 18 only for milk, and 15 only for teat skin. Thus, $38 \%(20 / 53)$ of the isolates originated from quarters found to be positive in both milk and teat skin, 34\% (18/53) from quarters positive in milk but negative in skin and $28 \%(15 / 53)$ from quarters positive in teat skin but negative in milk. All but one cow with Staph. aureus IMI in the current study had also previously been positive for Staph. aureus. The infection status of the one additional cow that was identified in this study with 2 Staph. aureuspositive quarters was previously unknown. Among the uninfected cows identified during the earlier whole-herd sampling (i.e., cows with no previous diagnosis of Staph. aureus IMI), only teat skin samples were found to be positive for Staph. aureus in the current study.
Without considering genotypic relatedness of the isolates (i.e., identifying the organism only at the species level), colonization of teat skin with Staph. aureus was highly significantly associated with also finding the organism in milk $(P<0.0001)$ : quarters colonized with Staph. aureus on teat skin had a 4.5 times higher risk of being diagnosed with Staph. aureus IMI than quarters negative on teat skin (relative risk $=4.51,95 \%$ CI for relative risk: 2.35 to 8.66 ).

\section{Distribution of Milk and Teat Skin Isolates Across PFGE Clusters}

One isolate from each positive milk and teat skin sample was typed using PFGE to assess the genotypic relatedness of the isolates. In total, 25 pulsotypes were recognized (Figure 1). Each pulsotype contained between 1 and 8 isolates, which often originated from both milk and teat skin. Isolates with $\geq 80 \%$ similarity were grouped into a cluster, and 3 clusters (named A, B, and C) were identified. All 3 clusters contained isolates from both milk and teat skin. Clusters A and B had isolates from all herds, whereas cluster $\mathrm{C}$ contained isolates exclusively from herd 1 . The distribution of the 53 Staph. aureus isolates (milk and teat skin) across the clusters was as follows: 8 isolates $(15.1 \%)$ were grouped in cluster A, $38(71.7 \%)$ in cluster B, and $7(13.2 \%)$ in cluster $\mathrm{C}$. Of the 38 isolates in the predominant cluster $\mathrm{B}, 60.5 \%$ originated from milk and $39.5 \%$ from teat skin. Clusters $\mathrm{A}$ and $\mathrm{C}$, on the other hand, contained more teat skin isolates than milk isolates (Figure 2). The majority $(60 \%)$ of the teat skin isolates $(15 / 25)$ came from quarters without Staph. aureus IMI. Teat skin isolates from uninfected quarters or cows were present in all 3 clusters.

Some cows contributed several isolates if they were infected in more than one quarter and their teat skin was also positive. Isolates originating from milk and teat skin of a same quarter of a cow were labeled as pairs (Table 2). In total, 10 pairs of isolates were found and they came from herd 1 (3 cows; 4 quarters) and herd 2 ( 3 cows; 6 quarters); no pairs were found in herd 3 or 4 . Genotypic variability was observed within the pairs, as isolates in 5 out of 10 pairs belonged to different clusters, whereas isolates in the other 5 pairs were identified in a same cluster. Also, within cows, quarters could be infected with isolates belonging to different clusters (Table 2 and Figure 1).

\section{Distribution of Virulence Factors in Teat Skin and Milk Isolates}

Of the 42 virulence factors, 14 ( $h l a, h l b, h l d, h l g A$, $h \lg B, h \lg C, \operatorname{luk} A, \operatorname{lukD}, \operatorname{lukE}, \mathrm{emp}, \mathrm{ebh}, f b p A, \operatorname{clf} A$, and 


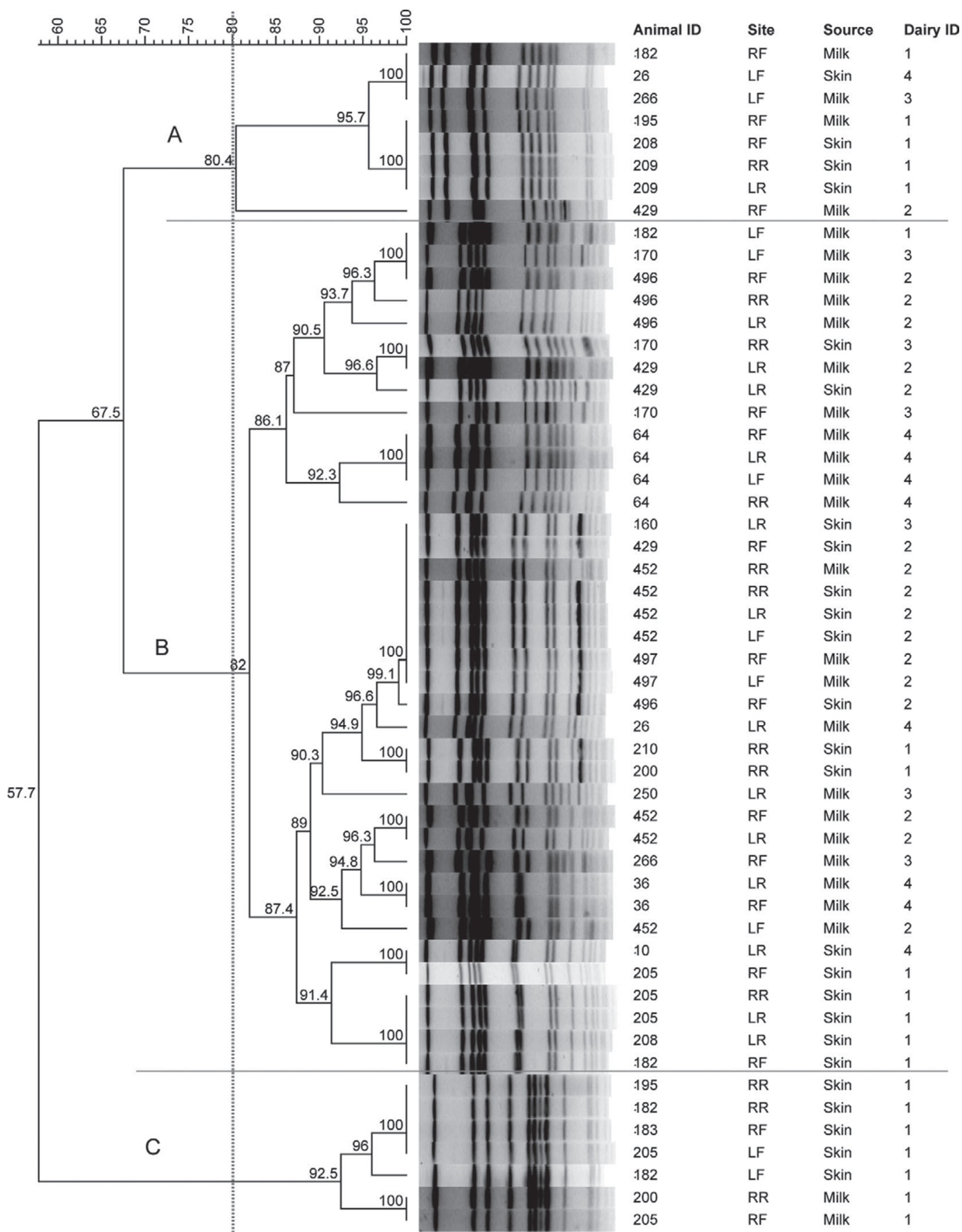

Figure 1. Dendrogram showing genetic relatedness of bovine Staphylococcus aureus isolates from milk and teat skin. Numbers at the upper left indicate the percentage of similarity; the dotted vertical line indicates $80 \%$ similarity cut-off; and horizontal lines indicate the 3 clusters identified (A, B, C). Site refers to different mammary quarters: $\mathrm{LF}=$ left front; $\mathrm{LR}=$ left rear; $\mathrm{RF}=$ right front; $\mathrm{RR}=$ right rear quarter; Dairy ID refers to herds 1 to 4 .

clfB) appeared highly conserved in both milk and skin isolates: at least $80 \%$ of the isolates carried them (Table $3)$. Virulence factor ear was identified only in one milk isolate, and 3 factors (lukF-pv, lukS-pv, and $c h p$ ) were not found at all in the study. Most enterotoxin genes were found at a relatively low frequency, with teat skin isolates carrying them in higher proportions than milk isolates. When the proportions of milk and teat skin isolates harboring different virulence factors were compared, a statistically significant difference was found for 
Table 2. Distribution of Staphylococcus aureus isolates from milk and teat skin of a same quarter of a cow across different pulsed-field gel electrophoresis clusters (A, B, C) by the herd of origin

\begin{tabular}{lcccc}
\hline Herd & Cow ID & & Cluster (milk/teat skin isolates; quarter $)^{1}$ \\
\hline 1 & $182^{2}$ & $\mathrm{~A} / \mathrm{B} ; \mathrm{RF}$ & $\mathrm{B} / \mathrm{C} ; \mathrm{LF}$ & \\
& 200 & $\mathrm{C} / \mathrm{B} ; \mathrm{RR}$ & & \\
& 205 & $\mathrm{C} / \mathrm{B} ; \mathrm{RF}$ & $\mathrm{B} / \mathrm{B} ; \mathrm{LR}$ & \\
2 & $452^{2}$ & $\mathrm{~B} / \mathrm{B} ; \mathrm{LF}$ & $\mathrm{BR}$ \\
& $429^{2}$ & $\mathrm{~B} / \mathrm{B} ; \mathrm{LR}$ & $\mathrm{A} / \mathrm{B} ; \mathrm{RF}$ & \\
& 496 & $\mathrm{~B} / \mathrm{B} ; \mathrm{RF}$ & & \\
\hline
\end{tabular}

${ }^{1} \mathrm{LF}=$ left front; $\mathrm{LR}=$ left rear; $\mathrm{RF}=$ right front; $\mathrm{RR}=$ right rear quarter.

${ }^{2}$ Cows 182 and 429 each had 2 quarters infected and cow 452 had 3 quarters infected. Herds 3 and 4 did not have any pairs of milk and teat skin isolates originating from the same quarter of a cow.

lukF', seh, sei, and sej (Table 3). All of these virulence factors were found more frequently $(P<0.05)$ in teat skin isolates than in those originating from milk. When comparing the proportion of teat skin isolates carrying different virulence factors from quarters with or without Staph. aureus IMI, no significant differences were detected.

Virulence factors clfA $(P=0.005), \operatorname{clfB}(P=0.004)$, and $f b p A(P=0.054)$ were more commonly harbored by isolates in the predominant cluster $\mathrm{B}$, whereas $f n p B$, sei, sem, and sen $(P<0.01)$ were more common in isolates belonging to the minor clusters $\mathrm{A}$ and $\mathrm{C}$ (Table $4)$.

\section{SCC and Bacterial Counts in Staph. aureus-Positive Milk Samples}

In $89 \%$ of the Staph. aureus positive milk samples, counts $>1,000 \mathrm{cfu} / \mathrm{mL}$ (10 colonies $/ 0.01 \mathrm{~mL}$ of milk) were found, and the remaining samples had counts of

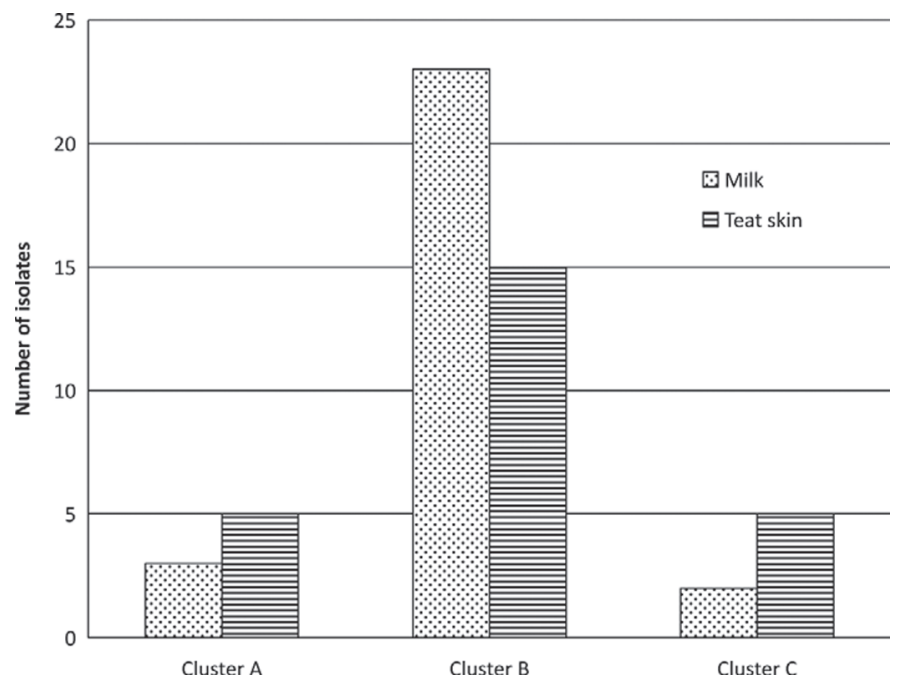

Figure 2. Distribution of bovine Staphylococcus aureus isolates from milk and teat skin across different pulsed-field gel electrophoresis clusters detected in 4 Ohio dairy herds. at least $500 \mathrm{cfu} / \mathrm{mL}$, suggesting moderate to abundant growth in all positive samples. Overall, $57 \%$ of the samples had >5,000 $\mathrm{cfu} / \mathrm{mL}, 32 \%$ had between 1,000 and $5,000 \mathrm{cfu} / \mathrm{mL}$, and $11 \%$ had 500 to $900 \mathrm{cfu} / \mathrm{mL}$.

Overall, SCC in milk from infected quarters was high; only 3 quarters had SCC $<400,000$ cells $/ \mathrm{mL}$ (the reason for using such a high cut-off value for categorizing quarters as low and high based on SCC), and the isolates from these quarters belonged to clusters $\mathrm{A}$ and $\mathrm{C}$. The median SCC in quarters from which the isolates in the clusters $\mathrm{A}, \mathrm{B}$, and $\mathrm{C}$ originated was $3.55 \times 10^{6}, 3.43 \times 10^{6}$, and $1.13 \times 10^{6}$ cells $/ \mathrm{mL}$, respectively, and no statistically significant differences were found when comparing SCC between clusters $(P$ $=0.80)$. Three virulence factors $(h l g B, c l f A$, and $c l f B)$ were significantly more common among isolates that originated from quarters with $\mathrm{SCC} \geq 400,000$ cells $/ \mathrm{mL}$ than among isolates from quarters with $\mathrm{SCC}<400,000$ cells/mL (Table 5). On the other hand, factors sei, sem, sen, and seu were significantly more common in isolates from quarters with SCC $<400,000$ cells $/ \mathrm{mL}$. Somatic cell count results were missing for 2 infected quarters.

\section{DISCUSSION}

The purpose of this study was to assess the role of teat skin colonization with Staph. aureus in Staph. aureus IMI by evaluating genotypic relatedness and virulence factors of Staph. aureus isolates from teat skin and milk. Colonization of teat skin with Staph. aureus was significantly associated with Staph. aureus IMI: quarters colonized with this organism on teat skin had 4.5 times higher risk of being diagnosed with Staph. aureus IMI than quarters negative on teat skin. In addition, Staph. aureus isolates from milk were closely related to those on teat skin: isolates from all 3 clusters were found both on teat skin and in milk from the infected mammary glands. These observations are in agreement with the results of Haveri et al. (2008), who also reported that Staph. aureus isolates from teat skin and teat canal were genetically indistinguishable from 
Table 3. Number and percentage of Staphylococcus aureus isolates from bovine milk and teat skin that carried different virulence factor genes

\begin{tabular}{|c|c|c|c|}
\hline \multirow[b]{2}{*}{ Gene(s) } & \multicolumn{2}{|c|}{ Number $(\%)$ of isolates with each gene } & \multirow[b]{2}{*}{$P$-value ${ }^{1}$} \\
\hline & Milk $(\mathrm{n}=28)$ & Teat skin $(\mathrm{n}=25)$ & \\
\hline luk $A$ & $28(100)$ & $25(100)$ & 1.00 \\
\hline$h l g A, h l g C, h l a, h l b, e m p, f b p A$ & $28(100)$ & $24(96)$ & 0.47 \\
\hline lukD, lukE, ebh & $27(96)$ & $25(100)$ & 1.00 \\
\hline hld & $26(93)$ & $25(100)$ & 0.49 \\
\hline clfA & $25(89)$ & $24(96)$ & 0.61 \\
\hline hlgB, $\operatorname{clf} B$ & $24(86)$ & $21(84)$ & 1.00 \\
\hline $\operatorname{lukB}$ & $20(71)$ & $17(68)$ & 1.00 \\
\hline$f n b A$ & $12(43)$ & $7(28)$ & 0.39 \\
\hline$f n b B$ & $4(14)$ & $8(32)$ & 0.19 \\
\hline $\operatorname{lukM}$ & $5(18)$ & $10(40)$ & 0.13 \\
\hline $\operatorname{lukF}$ & $4(14)$ & $11(44)$ & 0.03 \\
\hline ear & $1(4)$ & 0 & 1.0 \\
\hline$l u k F-p v, l u k S-p v, c h p$ & 0 & 0 & \\
\hline sea, ser, sec, see & 0 & $1(4)$ & 0.47 \\
\hline seb, seo, sep & 0 & 0 & \\
\hline sed & $5(18)$ & $9(36)$ & 0.21 \\
\hline seg & $4(14)$ & $5(20)$ & 0.72 \\
\hline seh & 0 & $4(16)$ & 0.04 \\
\hline sei & $7(25)$ & $14(56)$ & 0.03 \\
\hline sej & $2(7)$ & $9(36)$ & 0.02 \\
\hline sek & 0 & $3(12)$ & 0.10 \\
\hline sel & $2(7)$ & $2(7)$ & 1.00 \\
\hline sem & $2(7)$ & $6(24)$ & 0.13 \\
\hline sen & $2(7)$ & $3(12)$ & 0.66 \\
\hline$s e q$ & $2(7)$ & 0 & 0.49 \\
\hline seu & $3(11)$ & $4(16)$ & 0.70 \\
\hline tsst-1 & $1(4)$ & $2(8)$ & 0.60 \\
\hline
\end{tabular}

${ }^{1} P$-value indicates whether the proportion of milk and teat skin isolates carrying virulence factors differed significantly (based on Chi-squared or Fisher's exact test, as appropriate).

those isolated from infected mammary glands and that these sites could act as reservoirs for IMI. Other studies have reported that Staph. aureus isolates detected in extramammary sites or from the environment are genotypically the same as isolates from milk (Capurro et al., 2010; Mørk et al., 2012). However, because the current study was cross-sectional in nature, no directionality could be inferred.

Table 4. Distribution of virulence factors in bovine Staphylococcus aureus isolates (from milk and teat skin) across different pulsed-field gel electrophoresis clusters (predominant cluster B compared with minor clusters $\mathrm{A}$ and $\mathrm{C})^{1}$

\begin{tabular}{lrcc}
\hline & \multicolumn{2}{c}{ Cluster, no. (\%) } & \\
\cline { 2 - 3 } Factor & A and C $(\mathrm{n}=15)$ & $\mathrm{B}(\mathrm{n}=38)$ & P-value \\
\hline clfA & $11(73)$ & $38(100)$ & 0.005 \\
clfB & $9(60)$ & $36(95)$ & 0.004 \\
fnbB & $7(47)$ & $5(13)$ & 0.009 \\
fbp $A$ & $4(27)$ & $14(37)$ & 0.05 \\
sei & $11(73)$ & $10(26)$ & 0.004 \\
sem & $6(40)$ & $2(5)$ & 0.004 \\
sen & $4(27)$ & $1(3)$ & 0.03 \\
\hline
\end{tabular}

${ }^{1}$ Only factors whose proportions differed statistically significantly between the clusters are presented.
Even though isolates from all 3 clusters were shared between milk and teat skin, only a few milk-teat skin isolate pairs originating from a same quarter of a cow were found. In half of these pairs, the Staph. aureus isolates from teat skin were closely related (i.e., belonged to the same cluster), and in half of the pairs they were genetically different from those isolated from milk of the same quarter. In 2 cases, isolates from different clusters caused infections in different quarters of the same cow, similar to observations reported by Sabour

Table 5. Carriage of virulence factors (number of isolates; \% in parentheses) in bovine Staphylococcus aureus milk isolates originating from quarters with SCC greater than $(\mathrm{n}=23)$ or less than 400,000 cells $/ \mathrm{mL}(\mathrm{n}=3)^{1}$

\begin{tabular}{lccc}
\hline Factor & $\begin{array}{c}\mathrm{SCC}<400 \\
\left(\times 10^{3} \text { cells } / \mathrm{mL}\right)\end{array}$ & $\begin{array}{c}\mathrm{SCC} \geq 400 \\
\left(\times 10^{3} \text { cells } / \mathrm{mL}\right)\end{array}$ & $P$-value \\
\hline hlgB & $1(33)$ & $21(91)$ & 0.05 \\
clfA & $1(33)$ & $22(96)$ & 0.02 \\
clfB & 0 & $22(96)$ & 0.002 \\
sei & $3(100)$ & $4(17)$ & 0.013 \\
sem & $2(66)$ & 0 & 0.009 \\
sen & $2(66)$ & 0 & 0.009 \\
seu & $2(66)$ & $1(4)$ & 0.027 \\
\hline
\end{tabular}

${ }^{1}$ Only factors for which statistically significant differences were observed are presented. 
et al. (2004). The finding of dissimilar milk-teat skin pairs may be due to the fact that only one isolate per positive sample was saved and genotyped using PFGE. Haveri et al. (2008) reported finding different pulsotypes from a single sample when more than one isolate was chosen for PFGE typing, so it is possible that, had several isolates been genotyped, more strains and thus more matching pairs within quarters would have been found. This is supported by the fact that Staph. aureus IMI was highly significantly associated with teat skin being colonized with the same organism, even if isolates were not shown to belong to the same cluster. Herds 3 and 4 had the fewest positive samples in total, and no milk-teat skin pairs within a quarter were found in those herds; thus, the number of Staph. aureuspositive cows available for sampling at the time of the study may have limited the possibility of finding more pairs. Recent studies have shown that Staph. aureus is shed consistently in milk from naturally infected cows (Walker et al., 2011, 2013) but longitudinal studies on colonization of teat skin of dairy cows are lacking; thus, it is possible that if cows and quarters had been sampled repeatedly, a more detailed picture of Staph. aureus epidemiology, on a molecular level, may have emerged (Capurro et al., 2010).

Staphylococcus aureus can be found on teat skin of cows without an IMI, as reported by Haveri et al. (2008) and Piccinini et al. (2009), as well as observed in the current study. Without any indication of inflammation in the mammary gland (low SCC) and with a low Staph. aureus count $(\mathrm{cfu} / \mathrm{mL})$ in the milk sample, an isolate could simply be a contaminant from teat skin and not a cause of a true IMI (Middleton et al., 2002; Fournier et al., 2008; Piccinini et al., 2009), potentially affecting a correct diagnosis of an IMI. However, when using careful aseptic sampling procedures, contamination of a milk sample with Staph. aureus from teat skin appears unlikely. In the current study, the bacterial count was high in all milk samples found positive for Staph. aureus and almost all quarters also had high SCC. This is in agreement with Walker et al. (2013), who studied Staph. aureus shedding patterns throughout lactation and found Staph. aureus counts of at least $1,000 \mathrm{cfu} / \mathrm{mL}$ in the majority of samples. Additionally, all but 2 Staph. aureus-positive quarters (from the same cow) in the current study were from cows identified as being positive for Staph. aureus in earlier samplings, further diminishing the likelihood of contamination of milk samples from teat skin.

Staphylococcus aureus strains found on teat skin of cows without Staph. aureus IMI were genetically closely related to strains found in milk or skin of infected quarters. Zadoks et al. (2002) reported that Staph. aureus isolates from teat skin and milk can be found on milk- ing unit liners, implying that liners can be fomites for transmission of Staph. aureus. Contamination of bedding by milk leakage from Staph. aureus-infected quarters is also possible, especially among high-producing cows (Capurro et al., 2010). Thus, the possibility of contamination of teat skin with Staph. aureus isolates from milk cannot be fully dismissed. In the current study, over half of all teat skin isolates came from uninfected quarters, suggesting that Staph. aureus on teat skin is not a result of direct contamination from milk of that same quarter.

A higher proportion of isolates in cluster B carried the clf $A$ and $c l f B$ genes compared with isolates from the other clusters. Presence of these adherence genes, which are involved in the initial attachment of Staph. aureus to epithelial cells of the teat canal, may have contributed to the ability of these isolates to predominate and become established in these herds. This agrees with Haveri et al. (2008), who reported the presence of the adhesins $f n b A$ and $f n b B$ in their predominant PFGE types. Similarly, a significantly higher proportion of isolates from quarters with SCC $\geq 400,000$ cells $/ \mathrm{mL}$ carried these genes, corroborating results of Capurro et al. (2010a) and Fournier et al. (2008), who suggested that the dominance and pathogenicity of some Staph. aureus strains is likely due to differences between virulence factors of the strains.

A high percentage of Staph. aureus isolates from milk of cows with IMI have been reported to harbor different enterotoxin genes, implying that these toxins may be important in development of mastitis (Srinivasan et al., 2006; Rall et al., 2014). Larsen et al. (2000), however, questioned the role of these toxins in mastitis pathogenesis because only 1 of 414 isolates from cows with mastitis carried toxic genes in their study. In the current study, a higher proportion of teat skin isolates compared with milk isolates carried some virulence factor genes, suggesting that the presence of these factors may provide some advantage to endure in an adverse environment. The practices used to control mastitis such as pre- and postmilking teat dipping or potential abrasion caused by use of cloth or paper towels for teat cleaning before milking could be examples of these environmental challenges.

The current study found different enterotoxin genes at varying frequencies, ranging from 0 to $25 \%$ in milk isolates and from 0 to $56 \%$ in teat skin isolates. In general, the prevalence of enterotoxin genes in Staph. aureus strains from bovine milk with clinical or subclinical mastitis varies greatly, as discussed in Oliveira et al. (2011) and Srinivasan et al. (2006). These researchers suggested that this variability may be due to different environmental and management factors in different geographic regions. Occurrence of enterotoxin 
and tsst-1 genes in Staph. aureus may be of concern to consumers of raw milk because Staph. aureus is a common foodborne pathogen isolated from milk (Oliver et al., 2009).

The present study had some limitations that need to be considered when interpreting the results. A small number of herds was enrolled and only a portion of the cows in these herds were sampled for the purpose of the study. The sampling within the herds, however, was systematically stratified to identify known infected and uninfected cows and those whose Staph. aureus status was not known. Only one isolate from each positive sample was genotyped using PFGE, which may have limited our ability to find different Staph. aureus strains within a cow and a quarter and within a sample. Moreover, because this was a cross-sectional study, no inferences regarding causality or directionality can be made.

\section{CONCLUSIONS}

Results from PFGE genotyping demonstrated that some Staph. aureus isolates from milk and teat skin were closely related. Additionally, quarters colonized by Staph. aureus on teat skin were at a significantly higher risk of also having a Staph. aureus IMI compared with quarters negative on teat skin. The presence of particular virulence factors (e.g., clfA, clfB) may have contributed to the ability of certain isolates to become the predominant strain and to get established in those herds. Further investigation relating strain characteristics and presence of combinations of virulence factors to severity of infection will be of clinical interest.

\section{ACKNOWLEDGMENTS}

The authors thank the managers of the participating dairy herds and acknowledge the financial support of USDA Animal Health Formula Funds through the Council for Research at the College of Veterinary Medicine at the Ohio State University (Columbus).

\section{REFERENCES}

Bien, J., O. Sokolova, and P. Bozko. 2011. Characterization of virulence factors of Staphylococcus aureus: Novel function of known virulence factors that are implicated in activation of airway epithelial proinflammatory response. J. Pathog. 2011:601905.

Capurro, A., A. Aspan, K. Artursson, and K. P. Waller. 2010a. Genotypic variation among Staphylococcus aureus isolates from cases of clinical mastitis in Swedish dairy cows. Vet. J. 185:188-192.

Capurro, A., A. Aspan, H. Ericsson Unnerstad, K. Persson Waller, and K. Artursson. 2010. Identification of potential sources of Staphylococcus aureus in herds with mastitis problems. J. Dairy Sci. 93:180-191.

Enright, M. C., N. P. Day, C. E. Davies, S. J. Peacock, and B. G. Spratt. 2000. Multilocus sequence typing for characterization of methicillin-resistant and methicillin-susceptible clones of Staphylococcus aureus. J. Clin. Microbiol. 38:1008-1015.

Fournier, C., P. Kuhnert, J. Frey, R. Miserez, M. Kirchhofer, T. Kaufmann, A. Steiner, and H. U. Graber. 2008. Bovine Staphylococcus aureus: Association of virulence genes, genotypes and clinical outcome. Res. Vet. Sci. 85:439-448.

Haveri, M., M. Hovinen, A. Roslof, and S. Pyorala. 2008. Molecular types and genetic profiles of Staphylococcus aureus strains isolated from bovine intramammary infections and extramammary sites. J. Clin. Microbiol. 46:3728-3735.

Haveri, M., A. Roslof, L. Rantala, and S. Pyorala. 2007. Virulence genes of bovine Staphylococcus aureus from persistent and nonpersistent intramammary infections with different clinical characteristics. J. Appl. Microbiol. 103:993-1000.

Hogan, J. S., R. N. Gonzalez, R. J. Harmon, S. C. Nickerson, S. P. Oliver, J. W. Pankey, and K. L. Smith. 1999. Laboratory Handbook on Bovine Mastitis. National Mastitis Council Inc., Madison, WI.

Jarraud, S., M. A. Peyrat, A. Lim, A. Tristan, M. Bes, C. Mougel, J. Etienne, F. Vandenesch, M. Bonneville, and G. Lina. 2001. Egc, a highly prevalent operon of enterotoxin gene, forms a putative nursery of superantigens in Staphylococcus aureus. J. Immunol. 166:669-677.

Joo, Y. S., L. K. Fox, W. C. Davis, G. A. Bohach, and Y. H. Park. 2001. Staphylococcus aureus associated with mammary glands of cows: Genotyping to distinguish different strains among herds. Vet. Microbiol. 80:131-138.

Larsen, H. D., A. Huda, N. H. Eriksen, and N. E. Jensen. 2000. Differences between Danish bovine and human Staphylococcus aureus isolates in possession of superantigens. Vet. Microbiol. 76:153162

Middleton, J. R., L. K. Fox, J. M. Gay, J. W. Tyler, and T. E. Besser. 2002. Influence of Staphylococcus aureus strain-type on mammary quarter milk somatic cell count and $N$-acetyl-beta-D-glucosaminidase activity in cattle from eight dairies. J. Dairy Sci. 85:11331140 .

Mørk, T., B. Kvitle, and H. J. Jorgensen. 2012. Reservoirs of Staphylococcus aureus in meat sheep and dairy cattle. Vet. Microbiol. 155:81-87.

Mulvey, M. R., L. Chui, J. Ismail, L. Louie, C. Murphy, N. Chang, and M. Alfa., and Canadian Committee for the Standardization of Molecular Methods. 2001. Development of a Canadian standardized protocol for subtyping methicillin-resistant Staphylococcus aureus using pulsed-field gel electrophoresis. J. Clin. Microbiol. 39:3481-3485.

Oliveira, L., A. C. Rodrigues, C. Hulland, and P. L. Ruegg. 2011. Enterotoxin production, enterotoxin gene distribution, and genetic diversity of Staphylococcus aureus recovered from milk of cows with subclinical mastitis. Am. J. Vet. Res. 72:1361-1368.

Oliver, S. P., K. J. Boor, S. C. Murphy, and S. E. Murinda. 2009. Food safety hazards associated with consumption of raw milk. Foodborne Pathog. Dis. 6:793-806.

Park, J. Y., L. K. Fox, K. S. Seo, M. A. McGuire, Y. H. Park, F. R. Rurangirwa, W. M. Sischo, and G. A. Bohach. 2011. Detection of classical and newly described staphylococcal superantigen genes in coagulase-negative staphylococci isolated from bovine intramammary infections. Vet. Microbiol. 147:149-154.

Piccinini, R., L. Cesaris, V. Dapra, V. Borromeo, C. Picozzi, C. Secchi, and A. Zecconi. 2009. The role of teat skin contamination in the epidemiology of Staphylococcus aureus intramammary infections. J. Dairy Res. 76:36-41.

Rall, V. L., E. S. Miranda, I. G. Castilho, C. H. Camargo, H. Langoni, F. F. Guimaraes, J. P. Araujo Junior, and A. Fernandes Junior. 2014. Diversity of Staphylococcus species and prevalence of enterotoxin genes isolated from milk of healthy cows and cows with subclinical mastitis. J. Dairy Sci. 97:829-837.

Sabour, P. M., J. J. Gill, D. Lepp, J. C. Pacan, R. Ahmed, R. Dingwell, and K. Leslie. 2004. Molecular typing and distribution of Staphylococcus aureus isolates in eastern Canadian dairy herds. J. Clin. Microbiol. 42:3449-3455.

Sommerhäuser, J., B. Kloppert, W. Wolter, M. Zschock, A. Sobiraj, and K. Failing. 2003. The epidemiology of Staphylococcus aureus 
infections from subclinical mastitis in dairy cows during a control programme. Vet. Microbiol. 96:91-102.

Srinivasan, V., A. A. Sawant, B. E. Gillespie, S. J. Headrick, L. Ceasaris, and S. P. Oliver. 2006. Prevalence of enterotoxin and toxic shock syndrome toxin genes in Staphylococcus aureus isolated from milk of cows with mastitis. Foodborne Pathog. Dis. 3:274-283.

Sutra, L., and B. Poutrel. 1994. Virulence factors involved in the pathogenesis of bovine intramammary infections due to Staphylococcus aureus. J. Med. Microbiol. 40:79-89.

Tenhagen, B. A., N. Scheibe, B. A. Zucker, G. Koster, and W. Heuwieser. 2007. Staphylococcus aureus strains in primiparous and multiparous cows in six herds with a high prevalence of Staph. aureus intramammary infections. J. Dairy Res. 74:406-411.

Tenover, F. C., R. D. Arbeit, R. V. Goering, P. A. Mickelsen, B. E. Murray, D. H. Persing, and B. Swaminathan. 1995. Interpreting chromosomal DNA restriction patterns produced by pulsed-field gel electrophoresis: Criteria for bacterial strain typing. J. Clin. Microbiol. 33:2233-2239.

Tristan, A., L. Ying, M. Bes, J. Etienne, F. Vandenesch, and G. Lina. 2003. Use of multiplex PCR to identify Staphylococcus aureus adhesins involved in human hematogenous infections. J. Clin. Microbiol. 41:4465-4467.
Walker, J. B., P. J. Rajala-Schultz, W. L. Walker, J. L. Mathews, W. A. Gebreyes, and F. J. DeGraves. 2011. Variation in daily shedding patterns of Staphylococcus aureus in naturally occurring intramammary infections. J. Vet. Diagn. Invest. 23:1114-1122.

Walker, J. B., W. L. Walker, F. J. DeGraves, J. L. Mathews, W. A Gebreyes, and P. J. Rajala-Schultz. 2013. Staphylococcus aureus shedding pattern throughout lactation in dairy cows with naturally occurring intramammary infection. J. Am. Vet. Med. Assoc. 242:1410-1418.

Zadoks, R., W. van Leeuwen, H. Barkema, O. Sampimon, H. Verbrugh, Y. H. Schukken, and A. van Belkum. 2000. Application of pulsed-field gel electrophoresis and binary typing as tools in veterinary clinical microbiology and molecular epidemiologic analysis of bovine and human Staphylococcus aureus isolates. J. Clin. Microbiol. 38:1931-1939.

Zadoks, R. N., W. B. van Leeuwen, D. Kreft, L. K. Fox, H. W. Barkema, Y. H. Schukken, and A. van Belkum. 2002. Comparison of Staphylococcus aureus isolates from bovine and human skin, milking equipment, and bovine milk by phage typing, pulsed-field gel electrophoresis, and binary typing. J. Clin. Microbiol. 40:38943902 